\title{
UJI AKTIVITAS ANTIOKSIDAN EKSTRAK ETANOL KLIKA FALOAK (Sterculia quadrifida R.Br) DENGAN METODE DPPH (2,2-diphenyl-1-picrylhydrazyl)
}

\author{
Astuti Amin, Jeanny Wunas, Yuniven Merina Anin \\ Sekolah Tinggi Ilmu Farmasi Makassar \\ Jalan Perintis Kemerdekaan Km.13,7 Daya - Makassar 90242 \\ amin.astuti@gmail.com
}

\begin{abstract}
ABSTRAK
Telah dilakukan penelitian uji aktivitas antioksidan ekstrak etanol klika faloak dengan metode DPPH (2,2diphenyl-1-picrylhydrazyl). Tujuan dari penelitian ini adalah untuk menentukan aktivitas antioksidan ekstrak etanol kulit batang faloak terhadap radikal bebas $\mathrm{DPPH}$ berdasarkan nilai $\mathrm{IC}_{50}$. Klika faloak diekstraksi secara maserasi dengan menggunakan pelarut etanol dan dibuat dalam 5 seri konsentrasi yaitu 20 ppm, 40 ppm, 60 ppm, 80 ppm dan 100 ppm. Ekstrak diuji terhadap DPPH (2,2-diphenyl-1-picrihidrazyl) sebagai radikal bebas dan diukur pada panjang gelombang $516 \mathrm{~nm}$ dengan absorbansi 0,640 menggunakan spektrofotometer UV-Vis. Kemampuan antioksidan diukur sebagai penurunan absorbansi larutan DPPH setelah penambahan ekstrak. Hasil penelitian menunjukkan ekstrak etanol klika faloak (S. quadrifida R.Br) mempunyai aktivitas antioksidan kuat dengan nilai $\mathrm{IC}_{50} 4,8101 \mathrm{ppm}$ dan vitamin $\mathrm{C}$ sebagai kontrol positif mempunyai aktivitas antioksidan kuat dengan nilai $\mathrm{IC}_{50} 3,4873 \mathrm{ppm}$. Berdasarkan hasil yang diperoleh dapat disimpulkan bahwa ekstrak etanol klika faloak (S. quadrifida R.Br) memiliki aktivitas antioksidan yang lebih lemah dibandingkan dengan vitamin $\mathrm{C}$ sebagai kontrol positif.
\end{abstract}

Kata kunci : Antioksidan, klika faloak (Sterculia quadrifida R.Br), metode DPPH (2,2-diphenyl-1-picrylhydrazyl)

\section{PENDAhUluAN}

\section{A. Latar Belakang}

Radikal bebas (free radical) adalah suatu senyawa atau molekul yang mengandung satu atau lebih elektron tidak berpasangan pada orbital luarnya. Adanya elektron yang tidak berpasangan menyebabkan senyawa tersebut sangat reaktif mencari pasangan dengan cara menyerang dan mengikat elektron molekul yang berada disekitarnya. Akibatnya yaitu gangguan fungsi sel, kerusakan struktur sel, molekul termodifikasi yang tidak dapat dikenali oleh sistem imun, dan bahkan mutasi. Semua bentuk gangguan tersebut dapat memicu munculnya berbagai penyakit seperti penyakit degeneratif hingga kanker. Oleh sebab itu, tubuh kita memerlukan suatu substansi penting, yakni antioksidan yang dapat melindungi tubuh dari serangan radikal bebas dan meredam dampak negatifnya (Winarsi, 2007).

Antioksidan merupakan senyawa yang dapat menghambat reaksi oksidasi, dengan mengikat radikal bebas dan molekul yang sangat reaktif. Akibatnya, kerusakan sel dapat dihambat (Winarsi, 2007). Berdasarkan sumbernya, antioksidan dapat digolongkan menjadi 2 jenis yaitu antioksidan alami dan antioksidan sintesis. Namun adanya kekhawatiran terhadap efek samping antioksidan sintetik menjadikan antioksidan alami sebagai alternatif yang terpilih (Trilaksani, 2003).
Berdasarkan penelitian Atta-Ur-Rahman (2001), senyawa-senyawa yang mempunyai potensi sebagai antioksidan umumnya merupakan senyawa flavonoid, fenolat dan alkaloid. Senyawa flavonoid dan polifenolat bersifat antioksidan, antidiabetes, antikanker, antiseptik dan antiinflamasi, sedangkan alkaloid mempunyai sifat antineoplastik yang juga ampuh menghambat pertumbuhan sel-sel kanker.

Salah satu tanaman yang memiliki potensi sebagai antioksidan alami adalah Faloak ( $S$. quadrifida R.Br). Faloak merupakan salah satu tanaman yang tumbuh di provinsi Nusa Tenggara Timur (NTT). Bagian pohon Faloak yang sering digunakan adalah kulit batang (klika). Oleh masyarakat NTT, klika Faloak dipercaya dapat menyembuhkan berbagai penyakit seperti hepatitis, diabetes dan gangguan pencernaan. Klika Faloak mengandung senyawa antioksidan alami yaitu flavonoid dan senyawa fenolik yang mampu melindungi tubuh dari serangan radikal bebas (Siswadi et al, 2013). Adanya kandungan zat aktif tersebut maka diperlukan suatu kajian mengenai aktivitas antioksidan dari klika Faloak.

Pada penelitian ini dilakukan pengujian aktivitas antioksidan ekstrak etanol klika faloak $(S$. quadrifida R.Br) dengan metode DPPH (2,2diphenyl-1-picrylhydrazyl). Metode DPPH merupakan suatu metode untuk menentukan aktivitas antioksidan dalam sampel dengan melihat 
kemampuannya dalam menangkal radikal bebas senyawa 2,2-diphenyl-1-picrylhydrazyl.

Penelitian ini bertujuan untuk menentukan aktivitas antioksidan ekstrak etanol klika Faloak terhadap radikal bebas DPPH berdasarkan nilai $\mathrm{IC}_{50}$.

\section{METODE PENELITIAN A. Alat dan bahan}

Alat yang digunakan adalah bejana maserasi, cawan porselin, gelas piala, labu tentukur $10 \mathrm{ml}, 25$ $\mathrm{ml}, 50 \mathrm{ml}$ dan $100 \mathrm{ml}$, beaker gelas, erlenmeyer, vial, pipet mikro, pipet volume, pipet tetes, neraca analitik, tissue, alumunium foil, sendok tanduk, batang pengaduk dan spektrofotometer UV-VIS.

Bahan yang digunakan diantaranya adalah klika faloak, etanol 70\%, etanol pro analisis, DPPH (2,2 diphenyl-1-picrylhydrazil) dan Vitamin C

\section{B. Penyiapan sampel}

Sampel klika faloak yang diperoleh disortasi basah lalu dicuci. Sampel kemudian dirajang dan dikeringkan dengan cara diangin-anginkan kemudian dilakukan sortasi kering dan diserbukkan.

\section{Ekstraksi}

Sampel ditimbang sebanyak 250 gram dimaserasi dan diekstraksi dengan 1,75 liter etanol $70 \%$ selama 5 hari sambil sesekali diaduk kemudian disaring. Ampas dari hasil ekstraksi, diremaserasi selama 5 hari. Ekstrak cair yang diperoleh dikumpulkan dan diuapkan hingga diperoleh ekstrak kental.

\section{Uji pendahuluan golongan flavonoid}

$1 \mathrm{~g}$ ekstrak ditambah $5 \mathrm{ml} \mathrm{n}$-heksan dan $5 \mathrm{ml}$ air, dikocok dalam corong pisah. Dibiarkan beberapa saat hingga fase air dan n-heksan memisah kemudian pisahkan fase air dan fase n-heksan. Fase air ditambah $5 \mathrm{ml}$ metanol, dikocok dalam corong pisah dan diambil lapisan metanol dan ditambah $0,5 \mathrm{ml} \mathrm{HCl}$ pekat dan serbuk Magnesium. Positif flavonoid jika terbentuk warna merah ungu atau jingga. Fase nheksan ditambah $0,5 \mathrm{ml} \mathrm{HCl}$ pekat, dipanaskan, positif jika terbentuk warna merah.

\section{E. Uji Aktivitas Antioksidan}

Ekstrak dilarutkan dalam etanol p.a dan dibuat dalam berbagai konsentrasi yaitu 20, 40, 60, 80, dan 100 ppm sebanyak masing-masing $4 \mathrm{ml}$. Ke dalam masing-masing larutan ditambahkan $1 \mathrm{ml}$ larutan DPPH 0,4 mM dan diinkubasi pada selama 30 menit selanjutnya diukur pada panjang gelombang $516 \mathrm{~nm}$. Sebagai blanko digunakan etanol p.a dan DPPH 0,4 mM mM. Untuk pembanding digunakan Vitamin C murni (konsentrasi 2, 3, 4, 5 dan 6 ppm.
Perhitungan persen aktivitas antioksidan DPPH digunakan rumus sebagai berikut

Aktivitas antioksidan $(\%)=$

$$
\frac{(\text { A blanko }- \text { A sampel })}{\text { A blanko }} \times 100 \%
$$

A blanko = serapan radikal DPPH 0,4 mM

A sampel $=$ serapan radikal DPPH $0,4 \mathrm{mM}$ setelah diberi perlakuan sampel.

Aktivitas antioksidan peredaman radikal bebas DPPH ekstrak etanol klika faloak serta vitamin $\mathrm{C}$ dianalisis dan masing-masing dihitung harga $\mathrm{IC}_{50}$ nya melalui analisis probit. Selanjutnya, hasil analisis probit dibandingkan dengan tingkat kekuatan antioksidan (Jun et al, 2003).

\section{HASIL DAN PEMBAHASAN}

Klika faloak yang dipanen dibersihkan dan dirajang kemudian diekstraksi dengan metode maserasi. Metode ini digunakan karena metode ini merupakan metode dingin sehingga dapat mencegah kemungkinan rusaknya zat aktif akibat pemanasan selain itu metode ini memiliki kelebihan yaitu cara pengerjaan dan alat yang digunakan sederhana.

Pelarut yang digunakan dalam ekstraksi yaitu etanol $70 \%$ karena flavonoid merupakan senyawa yang larut dalam pelarut polar seperti etanol. Selain itu berdasarkan penelitian terhadap kandungan total fenolik dan aktivitas antioksidan dari ekstrak klika Ziziphus mucronata Willd. Subsp. yang dilakukan oleh Olajuyigbe et al (2011) menunjukkan bahwa ekstrak dengan pelarut etanol memiliki nilai kandungan total fenolik dan flavonoid serta aktivitas antioksidan tertinggi dibanding ekstrak dengan pelarut aseton.

Ekstrak cair klika setelah dipekatkan diperoleh ekstrak kental sebanyak 24,7232 gram dengan persentase rendamen sebesar 9,89\%. Hasil ekstraksi kemudian di uji kandungan kimia flavonoid dan didapatkan hasil positif yang ditandai dengan terbentuknya warna jingga.

Pengukuran aktivitas antioksidan sampel dilakukan pada panjang gelombang $516 \mathrm{~nm}$ yang merupakan panjang gelombang maksimum DPPH.

Adanya aktivitas antioksidan dari sampel mengakibatkan terjadinya perubahan warna pada larutan DPPH dalam metanol yang semula berwarna ungu pekat menjadi kuning pucat (Molyneux, 2004).

Tiap konsentrasi yang diperoleh kemudian diukur pada spektrofotometer UV-Vis dengan Vitamin C murni sebagai pembanding (kontrol positif). Aktivitas antioksidan ditunjukkan dengan nilai $\mathrm{IC}_{50}$ (Inhibitory Concentration 50\%). Nilai $\mathrm{IC}_{50}$ merupakan nilai konsentrasi antioksidan untuk meredam $50 \%$ aktivitas radikal bebas.

Uji aktivitas antioksidan atau penghambatan terhadap radikal bebas menggunakan metode DPPH 
menunjukkan bahwa ekstrak etanol klika faloak ( $S$. quadrifida $\mathrm{R}$. Br) memiliki aktivitas antioksidan.

Hasil pengujian aktivitas antioksidan dapat dilihat pada gambar 1 dan gambar 2 .

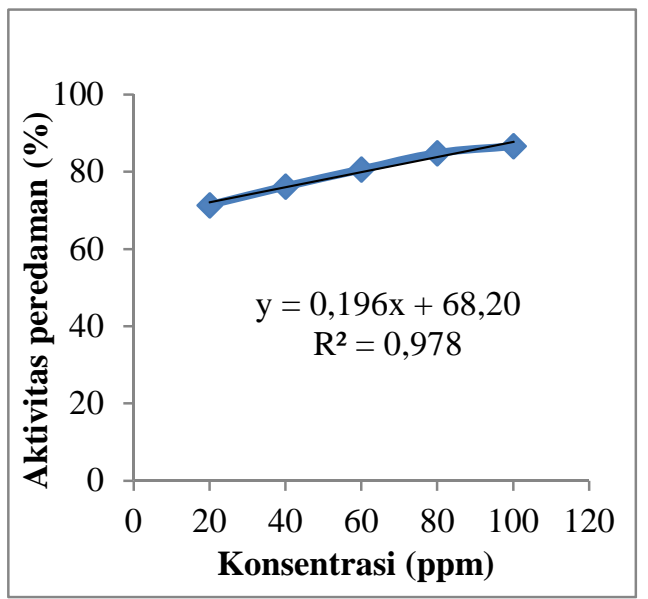

Gambar 1. Hubungan konsentrasi ekstrak etanol klika faloak dengan persen peredaman

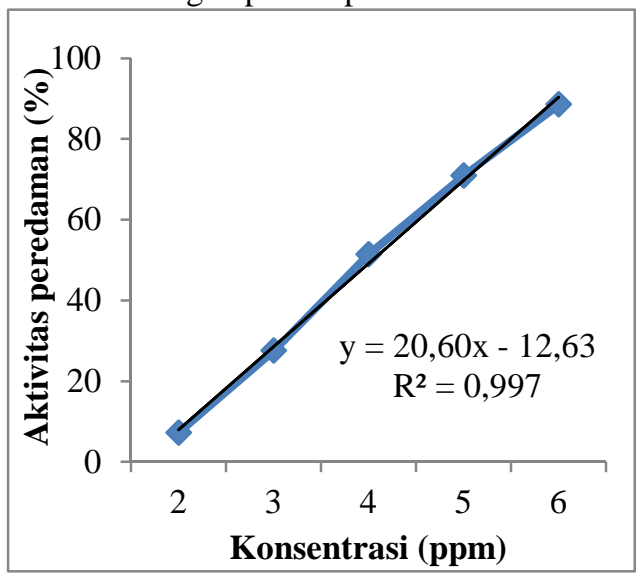

Gambar 2. Hubungan konsentrasi Vitamin C murni dengan persen peredaman

Berdasarkan analisis data menggunakan anilisis probit diperoleh nilai $\mathrm{IC}_{50}$ ekstrak etanol klika faloak sebesar 4, 8101 ppm dan Vitamin C murni sebagai pembanding mempunyai $\mathrm{IC}_{50}$ sebesar 3,8279 ppm. Nilai $\mathrm{IC}_{50}$ yang semakin kecil menunjukan aktivitas antioksidan pada bahan yang diuji semakin besar (Molyneux, 2004). Nilai IC $_{50}$ ekstrak etanol klika faloak lebih besar dari nilai $\mathrm{IC}_{50}$ Vitamin $\mathrm{C}$ murni. Hal ini menunjukkan bahwa daya antioksidan ekstrak etanol klika faloak lebih lemah dibandingkan antioksidan Vitamin $\mathrm{C}$ murni. Hal ini dapat disebabkan karena Vitamin C merupakan senyawa yang sangat murni sedangkan ekstrak etanol klika faloak masih merupakan ekstrak kasar bukan senyawa murni atau isolat.

Senyawa yang dicurigai memiliki aktivitas antioksidan pada ekstrak klika faloak adalah flavonoid dan senyawa fenolik. Menurut Kahkonen et al (1999) senyawa fenolik telah dilaporkan mempunyai aktivitas antioksidan karena sifat reduksinya. Flavonoid dapat beraksi sebagai antioksidan dengan menangkap radikal bebas melalui pemberian atom hidrogen pada radikal tersebut. Secara umum, kemampuan flavonoid dalam menangkap radikal tergantung dari substitusi gugus hidroksi dan kemampuan stabilisasi dari radikal fenolik melalui ikatan hidrogen atau melalui delokalisasi elektron. Selanjutnya radikal fenoksi flavonoid tersebut distabilkan oleh delokalisasi elektron yang tidak berpasangan di sekitar cincin aromatik. Stabilitas radikal fenoksi flavonoid (reactive oxygen) akan mengurangi kecepatan perambatan (propagasi) autooksidasi reaksi berantai.

\section{KESIMPULAN}

Dari hasil penelitian uji aktivitas antioksidan ekstrak etanol klika faloak (S. quadrifida R.Br) dengan metode DPPH (2,2-diphenyl-1-picryhydrazyl) maka disimpulkan bahwa ekstrak etanol klika faloak (S. quadrifida R. Br) mempunyai aktivitas antioksidan kuat dengan nilai $\mathrm{IC}_{50} 4,8101 \mathrm{ppm}$.

\section{DAFTAR REFERENSI}

Atta, U.R., M.I., Choudhary, 2001, Bioactive Natural Product a Potential Pharmacopores, A Theory of Memory, Pure appl. Chem, 73, p $555-560$

Jun, M.H.Y., J., Fong, X., Wan, C.S., Yang, C.T., Ho., 2003, Camparison of Antioxidant Activities of Isoflavones Form Kudzu Root (Puerarua labata O), Journal Food Science Institute of Technologist, 68; 2117-2122.

Kahkonen, M., P., et al., 1999, Antioxidant Activity of Plant Extracts Containing Phenolic Compounds, Journal of Agriculture and Food Cemistry, 47; 3954-3962

Molyneux, P., 2004, The Use of The Stable Free Radical Diphenyl picrylhydrazyl (DPPH) for Estimating Antioxidant Activity, Journal of Science and Technology Vol. 26 (2): 211-219

Olajuyigbe, O., P., and Afolayan, J., A., 2011, Phenolic Content and Antioxidant Property of the Bark Extracts of Ziziphus Mucronata Will. Subsp. Mucronata Will, BMC Complementary and Alternative Medicine 
Siswadi, S., S.G. dan Rianawati, H., 2013 'Potential Distribution and Utilization of Faloak (Sterculia quadrifida R.Br 1844)', Proceeding International Confrence of Forest and Biodiversity Manado, Editor : Langi. M, Manado Forestry Institute, Manado. p 165

Trilaksani, W., 2003, Antioksidan: Jenis, Sumber, Mekanisme dan Peran terhadap Kesehatan

Winarsi, H., 2007, Antioksidan Alami \& Radikal Bebas, Kasinus, Yogyakarta. 